\title{
Bimbingan Pribadi-Sosial Untuk Mengembangkan Perilaku Moral Siswa
}

\author{
Raodhatul Jannah \\ Bimbingan dan Konseling, Universitas Pendidikan Indonesia \\ Email: raodhatul18@gmail.com \\ Mamat Supriatna \\ Bimbingan dan Konseling, Universitas Pendidikan Indonesia \\ Email: mamatsupriatna@gmail.com
}

(Diterima: 08-April-2018; direvisi: 16-Mei-2018; dipublikasikan: 27-Juni-2018)

\begin{abstract}
The research is aimed to produce an effective social-personal guidance to develop students' moral behavior. This research uses quantitative approach with quasi experimental method and non-equivalent control group design to students class VIII of SMP Negeri 26 Bandung. Data analysis techniques used to find out the effectiveness of personal-social guidance in developing the moral behavior of students in SMP Negeri 26 Bandung Academic Year 2017/2018, include: 1) normality test; 2) homogeneity test; and 3) independent t test. The results show that in general social-personal guidance is not effective in developing students' moral behavior. But in particular there are five significant indicators, which is; 1) impose obligations as a child; 2) help others sincerely; 3) share / share information; 4) show concern for others; 5) guiding others to the task, and two insignificant indicators, namely; 1) understanding school rules; 2) consider the impact of lying.
\end{abstract}

Keywords: Moral Behavior; Personal-Social Guidance.

\begin{abstract}
Abstrak: Penelitian bertujuan untuk menghasilkan bimbingan pribadi-sosial yang efektif untuk mengembangkan perilaku moral siswa. Penelitian ini menggunakan pendekatan kuantitatif dengan metode kuasi eksperimen dan desain non-equivalent control group design terhadap siswa kelas VIII SMP Negeri 26 Bandung. Teknik analisis data yang digunakan untuk mengetahui gambaran efektivitas bimbingan pribadi-sosial dalam mengembangkan perilaku moral siswa di SMP Negeri 26 Bandung Tahun Ajaran 2017/2018, meliputi: 1) uji normalitas; 2) uji homogenitas; dan 3) uji independent t test. Hasil penelitian menunjukkan bahwa secara umum bimbingan pribadi-sosial tidak efektif dalam mengembangkan perilaku moral siswa. Namun secara khusus terdapat lima indikator yang signifikan, yakni; 1) menerapkan kewajiban sebagai seorang anak; 2) membantu orang lain dengan tulus; 3) membagi/berbagi informasi; 4) menunjukkan kepedulian pada orang lain; 5) membimbing orang lain mengerjakan tugas, dan dua indikator yang tidak signifikan, yakni; 1) memahami peraturan sekolah; 2) mempertimbangkan dampak berbohong.
\end{abstract}

Kata Kunci: Perilaku Moral, Bimbingan Pribadi-Sosial

Copyright (C 2018 Universitas Negeri Makassar.. This is an open access article under the CC BY-NC-ND license (http://creativecommons.org/licenses/by-nc-nd/4.0/). 


\section{PENDAHULUAN}

Setiap tahapan perkembangan moral individu selalu dihubungkan dengan perkembangan perilaku moral. Moral adalah ajaran tentang baik buruk suatu perbuatan dan kelakuan, akhlak, kewajiban, dan sebagainya (Purwadarminto, 1950,957). Moral diatur segala perbuatan yang dinilai baik dan perlu dilakukan, serta sesuatu perbuatan yang dinilai tidak baik dan perlu dihindari. Moral berkaitan dengan kemampuan seseorang untuk membedakan antara perbuatan yang benar dan yang salah. Dengan demikian, moral juga mendasari dan mengendalikan seseorang dalam bersikap dan berperilaku.

Individu dikatakan bermoral apabila perilaku orang tersebut sesuai dengan nilai-nilai moral yang dijunjung tinggi. Pada masa remaja, individu harus mengendalikan perilakunya sendiri agar sesuai dengan norma dan nilai yang berlaku di masyarakat, yang mana sebelumnya menjadi tanggung jawab guru dan orang tua. Perilaku moral adalah perilaku yang dilandasi atau dipikirkan sebelumnya oleh pelaku, berupa alasan dan motivasi yang bernilai moral (Kurtines \& Gerwitz, 1992). Sebaliknya suatu tindakan tidak dapat dipandang sebagai perilaku moral, apabila perilaku tidak dipikirkan oleh pelaku. Perilaku moral dikendalikan oleh konsepkonsep moral, peraturan perilaku yang menjadi kebiasaan bagi anggota, suatu budaya dan yang menentukan pola perilaku yang diharapkan dari seluruh anggota kelompok (Hurlock, 2011. 420).

Menurut Hurlock (Alwi, 2011) pelanggaran perilaku moral pada remaja awal yang umum terjadi di sekolah antara lain: mencuri, menipu, berbohong, menggunakan kata-kata kotor dan kasar, merusak milik sekolah, membolos, mengganggu anak yang lain dengan mengejek, menggertak, menciptakan gangguan, membaca komik atau mengunyah permen saat pelajaran, berbisik-bisik, melucu, membuat gaduh di kelas, berkelahi dengan teman sekelas, dan minum obat-obat terlarang.

Sejalan dengan bentuk pelanggaran perilaku moral remaja awal yang dipaparkan Hurlock, berikut hasil penelitian bentuk-bentuk perilaku moral siswa SMP di Kota Yogyakarta yang dilakukan oleh Saliman (2015). Populasi penelitian adalah siswa SMP kelas 9, baik negeri maupun swasta sebanyak 1624 siswa dengan sampel penelitian 216 siswa. Pulang ke rumah terlambat $81,01 \%$, berbohong kepada orang tua/orang lain $68,52 \%$, berbuat ulah sehinga guru marah $62,50 \%$, menonton film porno $11,69 \%$, penggunaaan uang SPP untuk kepentingan lain $9,26 \%$, sebagai kelompok geng $8,80 \%$, terlibat tawuran $8,33 \%$, menyontek saat ulangan $6,94 \%$, mengganggu orang lewat $5,56 \%$, memalsu tanda tangan presensi $5,56 \%$, membaca buku porno $3,24 \%$.

Penting bagi siswa berperilaku moral demi terwujudnya kehidupan yang damai penuh keteraturan, ketertiban, dan keharmonisan (Asrori \& Ali, 2014,136). Perilaku moral mendukung kemampuan perkembangan pribadi dan sosial siswa. Pada aspek perkembangan pribadi sosial, layanan bimbingan membantu siswa agar memiliki pemahaman diri, mengembangkan sikap positif, membuat pilihan kegiatan yang sehat, mampu menghargai orang lain, memiliki rasa tanggung jawab, mengembangkan keterampilan hubungan antar pribadi, dapat menyelesaikan masalah dan dapat membuat keputusan secara baik.

Dalam tulisan ini, secara konseptual perilaku moral dapat diartikan dalam dua istilah yakni moral action dan moral behavior. Menurut Piaget (Blasi, 1983) perilaku moral disebut sebagai moral action (tindakan moral) merupakan tindakan yang didahului oleh pengetahuan moral tentang benar atau salah. Selanjutnya Piaget (Duska \& Whelan, 1982) mengembangkan aspek dan indikator tindakan moral yaitu: a) perkembangan kesadaran akan peraturan, mencakup indikator tidak koersif, suci (tidak dapat di ganggu gugat), peralihan, modifikasi, b) erkembangan pelaksanaan peraturan, mencakup indikator aktivitas motorik, egosentris, kerjasama, kodifikasi, c) pertimbangan tentang benar dan salah, mencakup indikator perkataan salah yang dikatakan dengan sengaja, sesuatu yang tidak sungguh-sungguh benar, sesuatu yang tidak benar termasuk kekeliruan, perkataan yang nakal, d) persepsi tentang keadilan, mencakup indikator keadilan retributif, tanggung jawab kelompok atau solidaritas, keadilan imanen, keadilan distributif.

Perilaku moral disebut oleh Bandura (1990) sebagai moral behavior yang merupakan hasil dari moral knowing dan moral feeling. Menurut Bandura (Grusec, 2006) perilaku moral adalah perilaku positif dan negatif dari perilaku prososial dan antisosial yang ditentukan dari penguatan, hukuman, dan imitasi. Perilaku moral melibatkan aspek-aspek negatif dari perilaku mencontek, berbohong, dan mencuri. Aspekaspek positif termasuk membantu, berbagi, 
menghibur, membimbing, menyelamatkan, dan membela orang lain (Steinberg, 2011).

Perilaku moral merujuk kepada aspek perilaku prososial dan perilaku antisosial, yang dijabarkan sebagai berikut: a) perilaku prososial mencakup indikator membantu, berbagi, menghibur, membimbing, menyelamatkan, dan membela orang lain, b) perilaku antisosial mencakup indikator mencuri, mencontek, dan berbohong.

Kurtines \& Gerwitz (1984) menjelaskan perilaku moral merupakan suatu perbuatan yang diatur oleh aturan tertentu berdasarkan perspektif dari perilaku prososial. Perilaku moral merujuk pada aspek perilaku prososial yang dijabarkan sebagai berikut: a) perilaku berbagi atau memberi, mencakup indikator berbagi waktu, berbagi materi materi, dan berbagi informasi, b) perilaku membantu, mencakup indikator menyelamatkan, membela, atau memindahkan penyebab stress.

Berdasarkan pemaparan beberapa ahli, esensi perilaku moral adalah tindakan yang berbentuk perilaku prososial dan antisosial di kehidupan sehari-hari. Aspek perilaku moral meliputi; a) pengetahuan artinya individu memiliki kesadaran, pertimbangan, dan persepsi mengenai tindakan moral. Secara rinci indikatornya adalah: memandang peraturan sebagai hasil pemufakatan bersama, memandang perlu adanya penentuan peraturan, perkataan salah yang dikatakan dengan sengaja, menerapkan konsep hak dan kewajiban, b) perbuatan artinya perilaku positif dan negatif, indikatornya meliputi: membantu, berbagi, menghibur, membimbing, berbohong, dan mencuri.

Bimbingan pribadi-sosial dapat mengembangkan perilaku moral siswa, hal ini didasarkan pada aspek moral merupakan aspek pribadi dan sosial. Yusuf dan Nurihsan (2014, 11) mengemukakan bahwa yang tergolong dalam masalah-masalah sosial-pribadi adalah masalah hubungan dengan teman, lingkungan pendidikan dan masyarakat tempat tinggal mereka, dan penyelesaian konflik. Indikator-indikator yang terdapat pada masalah pribadi dan sosial remaja (siswa) antara lain yaitu, kurang memiliki sabar dan bersyukur, memiliki kebiasaan berbohong, menyontek, kurang disiplin, kurang menyenangi kritikan orang lain, dan tidak etis dalam pergaulan (Yusuf, 2011). Unsur-unsur dalam aspek pribadi-sosial secara substansi mencerminkan atau mengandung nilai-nilai moral yang secara silogis memiliki pengaruh.
Murro dan Kottman (1995) menegaskan elemen penting dalam aspek pribadi-sosial adalah mengembangkan konsep diri secara positif (developing a positive self concept) dan mengembangkan keahlian sosial secara tepat (developing appropriate social skills). American School Counselor Association (L. Bowers \& A. Hatch, 2002) menetapkan tujuan bimbingan pribadi-sosial untuk pencapaian keterampilan siswa dalam membuat keputusan, menentukan tujuan, dan mengambil tindakan yang diperlukan untuk mencapai tujuan tersebut. Tujuan yang dimaksud untuk memperoleh sikap, pengetahuan dan keterampilan interpersonal untuk membantu memahami dan menghormati diri sendiri dan orang lain.

Bimbingan pribadi-sosial untuk mengembangkan perilaku moral siswa dalam penelitian ini diartikan sebagai program yang diberikan oleh konselor untuk membantu individu dalam mengembangkan perilaku positif serta memecahkan masalah-masalah sosial, yang menekankan pada pendekatan kognitif dan perilau agar siswa mampu menerapkan perilaku moral dalam kehidupan sehari-hari. Struktur bimbingan pribadi-sosial untuk mengembangkan perilaku moral siswa mengacu pada Depdiknas (2016) yakni; rasional, deskripsi kebutuhan, tujuan, sasaran, struktur dan tahapan, dan evaluasi.

Adapun tujuan umum penelitian untuk menghasilkan bimbingan pribadi-sosial yang efektif untuk mengembangkan perilaku moral siswa.

\section{METODE}

Pendekatan yang digunakan dalam penelitian adalah pendekatan kuantitatif. Desain kuasi eksperimen yang digunakan Non Equivalent Control Group Design. Pendekatan kuantitatif digunakan dalam pemaparan tentang profil perilaku moral siswa dan pemaparan tentang gambaran efektifitas bimbingan pribadisosial untuk mengembangkan perilaku moral. Sehingga pendekatan ini dapat menjawab hipotesis penelitian secara spesifik.

Populasi dalam penelitian adalah seluruh siswa kelas VIII SMP Negeri 26 Bandung yang berjumlah 204 siswa. Pengambilan sampel penelitian dengan menggunakan teknik purposive sampling, yaitu teknik pengambilan sampel dengan pertimbangan tertentu (Sugiyono, 2015). Dasar pertimbangan pengambilan sampel dalam penelitian adalah 35 siswa di kelas VIII F, 
berdasarkan instrumen perilaku moral kelas tersebut skor rata-rata perilaku moral terendah, dan kelas VIII H pada kelompok kontrol.

Instrumen perilaku moral yang digunakan merupakan instrumen yang dikembangkan oleh peneliti berdasarkan teori moral action oleh Jean Piaget dan moral behavior oleh Albert Bandura dan Kurtinez \& Gerwitz. Tahap-tahap pengembangan instrumen meliputi penyusunan definisi konseptual, definisi operasional, kisi-kisi instrument, pedoman skoring dan penafsiran, serta pengujian instrumen. Pengujian instrumen diujicobakan di lapangan terbatas untuk mengetahui validitas dan reliabilitas. Instrumen penelitian dikatakan reliabel karena memiliki koefisien alpha 0,907 dengan derajat keterandalan sangat tinggi. Teknik analisis data menggunakan uji independent $t$ test.

\section{HASIL DAN PEMBAHASAN}

berikut.

Tabel 1. Profil Umum Perilaku Moral Siswa Kelas VIII SMP Negeri 26 Bandung Tahun Ajaran $2017 / 2018$

\begin{tabular}{|c|c|c|}
\hline Kategori & Interval & Profil \\
\hline Otonom & $X>220$ & 105 Siswa \\
\hline Semiotonom & $140 \leq X \leq 220$ & 99 Siswa \\
\hline Heteronom & $X<140$ & 0 Siswa \\
\hline
\end{tabular}

Berdasarkan tabel 1, mayoritas 105 siswa memiliki perilaku moral pada kategori otonom, sisanya 99 siswa berada pada proporsi kategori semiotonom dan tidak ada siswa yang berada pada kategori heteronom. Perilaku moral siswa kategori semiotonom artinya, siswa memahami bahwa aturan yang berasal dari luar dirinya dapat diubah menurut aturan-aturan yang dibuat olehnya, tetapi siswa belum dapat melepaskan diri dari pengaruh orang lain. Selanjutnya perilaku moral siswa pada kategori otonom artinya, siswa mampu berpikir perlunya memodifikasi aturan-aturan untuk disesuaikan dengan situasi dan kondisi yang baik. Siswa bertindak dengan mempertimbangkan intensi pelaku dan konsekuensinya. Kemudian pada kategori heteronom artinya, siswa cenderung menerima begitu saja segala aturan yang diberikan oleh orang-orang yang dianggap kompeten. Peraturan dipahami sebagai sesuatu yang tidak dapat diubah.

Setelah dipaparkan profil perilaku moral secara umum, berikutnya disampaikan berdasarkan aspek dan indikator perilaku moral sebagaimana tampak pada tabel berikut.

Tabel 2. Profil Perilaku Moral Siswa Berdasarkan Aspek Pengetahuan

\begin{tabular}{clccc}
\hline \multirow{2}{*}{ Aspek } & \multicolumn{2}{c}{ Indikator } & \multicolumn{3}{c}{ Profil } \\
\cline { 3 - 5 } Pengetahuan & $\begin{array}{l}\text { Memahami peraturan } \\
\text { sekolah }\end{array}$ & 185 & 19 & 0 \\
\hline $\begin{array}{l}\text { Mempertimbangkan } \\
\text { dampak berbohong } \\
\text { Menerapkan kewajiban } \\
\text { sebagai seorang anak }\end{array}$ & 185 & 19 & 0 \\
\hline
\end{tabular}

Berdasarkan tabel 2, pada indikator memahami peraturan sekolah yang berada pada klasifikasi otonom 185 siswa, artinya siswa mampu memahami peraturan sekolah tanpa adanya pengaruh dari orang lain, sedangkan pada 19 siswa yang berada pada klasifikasi semiotonom dapat memahami peraturan sekolah dengan pengaruh orang lain. Pada indikator mempertimbangkan dampak berbohong yang berada pada klasifikasi otonom 185 siswa, artinya siswa mampu mempertimbangkan dampak dari berbohong dengan memodifikasi 
pikirannya tanpa pengaruh dari orang lain, sedangkan 19 siswa pada klasifikasi semiotonom mampu mempertimbangkan dampak berbohong karena dengan adanya pengaruh dari orang lain. Pada indikator menerapkan kewajiban sebagai seorang anak yang berada pada klasifikasi otonom 146 siswa, artinya siswa mampu menerapkan kewajiban sebagai seorang anak dengan penuh kesadaran diri, sedangkan 58 siswa pada klasifikasi semiotonom mampu menerapkan kewajiban sebagai seorang anak atas pengaruh dari orang lain.

Selanjutnya pada aspek perbuatan dapat dilihat pada tabel berikut.

Tabel 3. Profil Perilaku Moral Siswa Berdasarkan Aspek Perbuatan

\begin{tabular}{clccc}
\hline \multirow{2}{*}{ Aspek } & \multicolumn{1}{c}{ Indikator } & \multicolumn{3}{c}{ Profil } \\
\cline { 3 - 5 } & $\begin{array}{l}\text { Membantu orang } \\
\text { dengan tulus }\end{array}$ & Otonom & Semiotonom & Heteronom \\
\hline $\begin{array}{l}\text { Membagi/berbagi } \\
\text { informasi }\end{array}$ & 20 & 172 & 12 \\
\hline $\begin{array}{l}\text { Menunjukkan } \\
\text { kepedulian } \\
\text { orang lain kepada } \\
\begin{array}{l}\text { Membimbing orang lain } \\
\text { mengerjakan tugas }\end{array}\end{array}$ & 126 & 120 & 12 \\
\hline
\end{tabular}

Berdasarkan tabel 3, pada indikator membantu orang lain dengan tulus yang berada pada klasifikasi otonom 20 siswa, artinya siswa membantu orang lain dengan tulus tanpa pengaruh orang lain melainkan kesadaran diri akan membantu orang lain. Sedangkan 172 siswa pada klasifikasi semiotonom membantu orang lain berdasarkan pengaruh dari orang lain dan 12 siswa pada klasifikasi heteronom membantu orang lain bukan karena keinginan tulus membantu melainkan atas perintah dari orang lain. Pada indikator membagi/berbagi informasi yang berada pada klasifikasi otonom 72 siswa, artinya siswa mampu membagi/berbagi informasi, 120 siswa pada klasifikasi semiotonom membagi/berbagi informasi berdasarkan pengaruh dari orang lain, dan 12 siswa pada klasifikasi heteronom membagi/berbagi informasi atas perintah dari orang lain. Pada indikator menunjukkan kepedulian kepada orang lain yang berada pada klasifikasi otonom 80 siswa, artinya siswa mampu berlaku empati pada orang lain, 121 siswa pada klasifikasi semiotonom menunjukkan kepedulian pada orang lain berdasarkan pengaruh orang lain, dan 3 siswa pada klasifikasi heteronom menunjukkan kepedulian pada orang lain karena perintah dari orang lain. Pada indikator membimbing orang lain mengerjakan tugas yang berada pada klasifikasi otonom 126 siswa, artinya siswa mampu membimbing orang lain mengerjakan tugas dengan penuh rasa tanggung jawab, 78 siswa pada klasifikasi semiotonom membimbing orang lain mengerjakan tugas atas dasar pengaruh orang lain.

Hasil uji statistik bimbingan pribadisosial bertujuan sebagai upaya memperoleh keyakinan data empirik tentang pengaruh intervensi yang dilakukan terhadap pengembangan perilaku moral siswa. Prosedur yang ditempuh untuk mengetahui keberhasilan bimbingan pribadi-sosial untuk mengembangkan perilaku moral siswa dengan pengujian hipotesis. Hipotesis dirumuskan "bimbingan pribadi-sosial efektif untuk mengembangkan perilaku moral siswa". Hasil data memenuhi asumsi normalitas dan homogenitas maka digunakan uji $t$ (Independent $t$ test) gain score. Hipotesis yang diuji pada penelitian adalah:

$\mathrm{Ha}=$ bimbingan pribadi-sosial efektif untuk mengembangkan perilaku moral siswa.

Berdasarkan skor rata-rata bimbingan pribadi-sosial untuk mengembangkan perilaku moral siswa memiliki daya pengaruh yang baik, yaitu dapat mengembangkan perilaku moral siswa. Peningkatan perilaku moral siswa terlihat pada perubahan skor rata-rata. Perbedaan pretest dan posttest perilaku moral siswa kelas eksperimen yang disajikan pada tabel 4.5 sebagai berikut.

Tabel 4. Hasil Perhitungan Rerata Pre-test dan Post-test Kelas Eksperimen 


\begin{tabular}{llrrrr}
\hline Kelas Eksperimen & Mean & N & Std. Deviation & \multicolumn{2}{c}{$\begin{array}{c}\text { Std. Error } \\
\text { Mean }\end{array}$} \\
\hline Pair 1 & Pretest & 226.89 & 35 & 25.438 & 4.300 \\
& Posttest & 232.49 & 35 & 31.070 & 5.252 \\
\hline
\end{tabular}

Hasil perhitungan rerata pre-test dan post-test kelas eksperimen menunjukkan rata-rata skor pretest yang didapatkan sebesar 226,89 sedangkan rata-rata posttest sebesar 232,49. Hasil rata-rata skor menunjukkan bahwa ada perubahan setelah diberikan bimbingan pribadi- sosial atau adanya peningkatan perilaku moral siswa di kelas eksperimen.

Sedangkan perbedaan pretest dan posttest perilaku moral siswa pada kelas kontrol disajikan pada tabel 5 sebagai berikut.

Tabel 5. Hasil Perhitungan Rerata Pre-test dan Post-test Kelas Kontrol

Hasil perhitungan rerata pre-test dan post-test kelas kontrol menunjukkan rata-rata skor pretest yang didapatkan sebesar 227,63 sedangkan rata-rata post-test sebesar 229,40. Hasil rata-rata skor menunjukkan bahwa adanya peningkatan perilaku moral siswa di kelas kontrol.

Selanjutnya dilakukan uji Independent $T$ dengan membandingkan antara gain skor posttest kelompok eksperimen dan kelompok kontrol. Uji Independent T Test gain score digunakan dengan asumsi hasil analisis pretest kelompok eksperimen dan kelompok kontrol berdistribusi normal dan homogen (Sugiyono, 2016, hlm. 212). Hasil Uji Independent T Test dapat dilihat pada tabel berikut.

\begin{tabular}{lllrrr}
\hline & Kelas Kontrol & Mean & N & Std. Deviation & \multicolumn{2}{c}{$\begin{array}{c}\text { Std. Error } \\
\text { Mean }\end{array}$} \\
\hline Pair 1 & Pretest & 227.63 & 35 & 26.210 & 4.430 \\
\cline { 2 - 6 } & Posttest & 229.40 & 35 & 22.673 & 3.832 \\
\hline
\end{tabular}

Test gain score untuk menguji hipotesis. Caranya

Tabel 6. Tabel Hasil Uji Independent T test Gain Score

Independent Samples Test

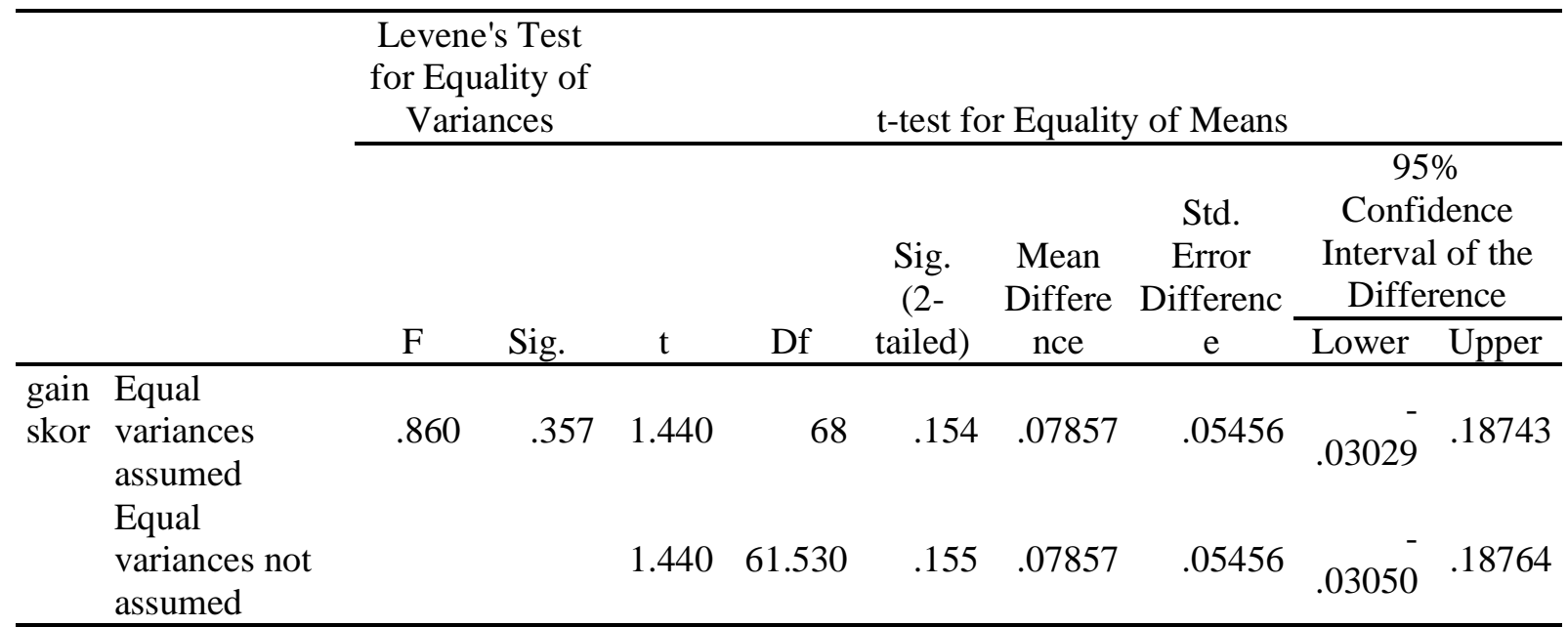


Berdasarkan hasil uji independent t test gain score pada tabel 6 nilai Sig (2 tailed) sebesar 0,154 . Karena 0,154 > 0,05 maka diperoleh hasil bahwa hipotesis penelitian ditolak. Dengan demikian bimbingan pribadi-sosial tidak efektif untuk mengembangkan perilaku moral siswa.

Setelah dilakukan pengolahan data secara keseluruhan, berikut dipaparkan perubahan skor pada aspek dan indikator perilaku moral siswa kelas eksperimen sebelum dan sesudah memperoleh bimbingan pribadi-sosial menggunakan gain score dengan bantuan SPSS 22 for Windows.

Tabel 7. Akumulasi uji efektivitas bimbingan pribadi-sosial Terhadap peningkatan tiap indikator perilaku moral kelompok eksperimen

\begin{tabular}{|c|c|c|c|c|c|c|}
\hline Aspek & $\begin{array}{c}\text { Indikator Perilaku } \\
\text { Moral }\end{array}$ & $\begin{array}{c}\text { Skor Pre- } \\
\text { test }\end{array}$ & $\begin{array}{c}\text { Skor } \\
\text { Post-test }\end{array}$ & $\begin{array}{c}\text { Gain } \\
\text { Score }\end{array}$ & $\begin{array}{c}\text { Sig } 2 \\
\text { (tailed) }\end{array}$ & Ket \\
\hline \multirow{3}{*}{ Pengetahuan } & $\begin{array}{l}\text { Memahami peraturan } \\
\text { sekolah }\end{array}$ & 37,11 & 37,42 & 0,039 & 0,477 & Tdk Sig \\
\hline & $\begin{array}{l}\text { Mempertimbangkan } \\
\text { dampak berbohong }\end{array}$ & 24,11 & 24,15 & 0,006 & 0,869 & Tdk Sig \\
\hline & $\begin{array}{ll}\text { Menerapkan } & \\
\text { kewajiban } & \text { sebagai } \\
\text { seorang anak } & \end{array}$ & 39,82 & 48,62 & 0,844 & 0,000 & Sig \\
\hline \multirow{5}{*}{ Perbuatan } & $\begin{array}{l}\text { Membantu orang lain } \\
\text { dengan tulus }\end{array}$ & 31,74 & 33,11 & 0,075 & 0,037 & Sig \\
\hline & $\begin{array}{l}\text { Membagi/berbagi } \\
\text { informasi }\end{array}$ & 19,97 & 22,02 & 0,204 & 0,045 & Sig \\
\hline & Menunjukkan & & & & & \\
\hline & $\begin{array}{l}\text { kepedulian pada orang } \\
\text { lain }\end{array}$ & 34,42 & 36,11 & 0,159 & 0,028 & Sig \\
\hline & $\begin{array}{l}\text { Membimbing orang } \\
\text { lain mengerjakan tugas }\end{array}$ & 31,57 & 38,59 & 0,832 & 0,000 & Sig \\
\hline
\end{tabular}

$* \alpha=0,05$

Berdasarkan hasil analisis data pretest dan posttest pada setiap indikator perilaku moral siswa, terdapat 2 indikator yang tidak signifikan, indikator yang dimaksud yaitu: 1) memahami peraturan sekolah nilai Sig (2 tailed) sebesar $0,477>0,05$, dan 2) mempertimbangkan dampak berbohong nilai Sig (2 tailed) sebesar $0,869>$ 0,05 . Kesimpulannya memahami peraturan sekolah dan mempertimbangkan dampak berbohong tidak efektif untuk mengembangkan perilaku moral siswa.

Berdasarkan uji efektivitas hasilnya bimbingan pribadi-sosial tidak efektif untuk mengembangkan perilaku moral siswa. Ketidakefektifan terjadi karena tidak ada keselarasan antara teori perilaku moral yang digunakan dengan teori bimbingan pribadisosial. Program bimbingan pribadi-sosial disusun bukan berdasarkan teori melainkan berdasarkan kebijakan departemen pendidikan nasional yang dijadikan acuan dalam penyusunan program. Tetapi, terdapat pengaruh antara bimbingan pribadi-sosial terhadap perilaku moral yang terlihat pada rata-rata perubahan skor perilaku moral yang dialami oleh siswa. Dibandingkan kelompok kontrol, siswa pada kelompok eksperimen lebih banyak mengalami kenaikan rata-rata skor perilaku moral meskipun hasilnya bervariasi pada setiap siswa.

Secara teoretik, perkembangan moral otonom muncul pada saat anak berumur 10 sampai 12 tahun, anak mendefiniskan bohong sebagai "pernyataan salah yang dikatakan sengaja". Oleh karena itu, pada usia remaja individu sudah dapat berpikir otonom karena pada usia 13-14 tahun siswa berada pada tahap operasional formal. Namun, faktanya dalam penelitian siswa kelas VIII yang berumur 13-14 tahun masih terdapat 99 siswa yang berada pada tahap semiotonom yakni berperilaku moral berdasarkan pengaruh dari orang lain. Fakta yang ditemukan, sejalan dengan penelitian maupun studi yang menemukan bahwa banyak siswa bahkan mahasiswa walaupun usianya telah 
melampaui, belum dapat melakukan formal operation (Budiningsih, 2004, 40).

Pengujian efektivitas bimbingan pribadisosial juga dilakukan berdasarkan indikator perilaku moral melalui uji gain score, menegaskan bahwa bimbingan pribadi-sosial dapat mengembangkan indikator menerapkan kewajiban sebagai seorang anak, membantu orang lain dengan tulus, membagi/berbagi informasi, menunjukkan kepedulian pada orang lain, dan membimbing orang lain mengerjakan tugas. Tetapi juga ditemukan dua indikator yang tidak efektif yaitu indikator memahami peraturan sekolah dan mempertimbangkan dampak berbohong. Indikator memahami peraturan sekolah termasuk dalam konsep perkembangan kesadaran akan peraturan. Menurut Piaget keyakinan seluruh moralitas terkandung dalam sistem peraturan, dari hakikat seluruh moralitas harus dicari dalam sikap hormat terhadap peraturan (Duska \& Whelan, 1982, 18). Jika demikian, tindakan moral pada indikator memahami peraturan sekolah adalah bagaimana pikiran individu sampai pada sikap hormat terhadap suatu aturan. Dengan kata lain sejauh mana peraturan dianggap sebagai sesuatu yang membatasi tingkah laku. Upaya yang dapat dilakukan pada indikator memahami peraturan sekolah menurut Piaget melalui permainan kooperatif dan kematangan kognitif yang lebih besar.

Pada indikator mempertimbangkan dampak berbohong termasuk dalam konsep pertimbangan tentang benar dan salah yang menurut Piaget, ada periode di mana peraturan moral dianggap sebagai suci dan tidak dapat diganggu gugat, dan di mana pelaksanaan peraturan bersifat egosentris, yaitu melalui meniru apa yang dilihat. Periode pemahaman peraturan moral seperti itu oleh Piaget disebut periode realisme moral, yang didefinisikan sebagai kecenderungan melihat kewajiban dan nilainya sebagai suatu yang berdiri sendiri dan ada di luar akal manusia, sebagai sesuatu yang memaksa entah bagaimana keadaan seseorang (Duska \& Whelan, 1982, 25). Upaya yang dapat dilakukan pada indikator mempertimbangkan dampak berbohong menurut Piaget dengan menjelaskan seberapa jeleknya berbohong dan alasan-alasan sebab apa orang tidak boleh berbohong melalui cerita dilemma moral.

Sejalan dengan pendapat Bandura (Santrock, 2015) yang menganggap remaja yang memiliki kematangan kognitif yang tinggi belum tentu dapat berperilaku moral, sehingga perilaku moral terbentuk berdasarkan pengalaman remaja meniru dan mengimitasi perilaku orang dewasa di lingkungannya. Pembentukan perilaku moral ditentukan kemampuan remaja mengatur dirinya, untuk mengontrol perilaku yang sesuai dengan harapan masyarakat.

Perlunya reinforcement pada setiap perilaku remaja karena terkadang remaja masih perlu diingatkan atau dikuatkan perilakunya. Perkembangan moral dapat berlangsung melalui beberapa cara, diantaranya melalui pendidikan langsung, yaitu melalui penanaman pengertian tentang tingkah laku yang benar dan salah, atau baik dan buruk oleh orangtua, guru atau orang dewasa lainnya. Di samping itu, yang paling penting dalam pendidikan moral adalah keteladanan dari orang tua, guru atau orang dewasa lainnya dalam melakukan perilaku moral. Kedua, melalui identifikasi, yaitu dengan cara mengidentifikasi atau meniru penampilan atau tingkah laku moral seseorang yang menjadi idolanya (seperti orang tua, guru, kiayi, artis, atau orang dewasa lainnya). Terakhir, melalui proses coba-coba (trial \& error), yaitu dengan cara mengembangkan perilaku moral secara cobacoba. Perilaku yang mendatangkan pujian atau penghargaan akan terus di kembangkan, sementara perilaku yang mendatangkan hukuman atau celaan akan dihentikannya (Yusuf, 2011, hlm. 134).

\section{SIMPULAN DAN SARAN}

Berdasarkan hasil penelitian yang diperoleh disimpulkan bahwa penelitian bimbingan pribadi-sosial untuk mengembangkan perilaku moral siswa menggunakan metode diskusi dan latihan, berjumlah 35 siswa kelas VIII F SMP Negeri 26 Bandung Tahun Ajaran 2017/2018 melalui tahapan studi pendahuluan, pengembangan instrumen, uji kelayakan instrumen, pengembangan bimbingan pribadisosial, uji kelayakan bimbingan pribadi-sosial, dan uji coba bimbingan pribadi sosial. Hasil penelitian menunjukkan bimbingan pribadisosial untuk mengembangkan perilaku moral siswa secara umum tidak efektif, sedangkan secara khusus terdapat lima indikator yang signifikan, yakni; 1) menerapkan kewajiban sebagai seorang anak; 2) membantu orang lain dengan tulus; 3) membagi/berbagi informasi; 4) menunjukkan kepedulian pada orang lain; 5) membimbing orang lain mengerjakan tugas, dan dua indikator yang tidak signifikan, yakni; 1) 
memahami peraturan sekolah; mempertimbangkan dampak berbohong.

Rekomendasi penelitian diarahkan untuk mengembangkan program bimbingan pribadisosial dengan menggunakan metode yang berbeda, menyusun program bimbingan pribadisosial berdasarkan teori, dan adanya prasyarat bagi siswa yang diberikan intervensi untuk mematangkan kognitif melalui rekonstruksi kognitif, agar tercapainya pengembangan moral otonom melalui bimbingan pribadi-sosial. Bagi pengembangan penelitian selanjutnya perlu memperhatikan dari segi metode, instrumen penelitian, dan rancangan program bimbingan pribadi-sosial.

\section{DAFTAR RUJUKAN}

Asrori, M. \& Ali, M. (2014). Psikologi remaja perkembangan peserta didik. Jakarta: PT Bumi Aksara.

Bandura, A. (1990). Selective activation and disengagement of moral control. Journal of Social Issues.

Budiningsih, A. (2004). Belajar dan pembelajaran. Yogyakarta: Penerbit Rineka Cipta.

Duska \& Whelan. (1982). (a.b Dwija Atmaka) Perkembangan moral : perkenalan dengan piaget dan kohlberg. Yogyakarta : Kanisius.
Depdiknas. (2016). Panduan operasional penyelenggaraan bimbingan dan konseling di sekolah menengah pertama (SMP).

Kurtines, M. \& Gerwitz, L. (1992). Moralitas, perilaku moral, dan perkembangan moral. Jakarta: UI-Press.

L. Bowers \& A. Hatch. (2002). The national model for school counseling program.

American School Counselor Association.

Muro, J. \& Kottman, T. (1995). Guidance and counseling in elementery school and middle school. Iowa: Brown and Benchmark Publisher.

Saliman. (2015). Bentuk-bentuk kenakalan siswa SMP di Kota Yogyakarta. JIPSINDO. 2 (2), hlm. 179-201.

Santrock, W. (2015). Adolescence. New York: McGraw-Hill.

Steinberg, L., Bornstein, M. H., Vandell, D. L., dan Rook, K. S. 2011. Life Span Development. USA: Wadsworth Cengange Learning

Sugiyono. (2016). Metode penelitian kombinasi (mixed methods). Bandung: Alfabeta.

Yusuf, S. (2011). Psikologi perkembangan anak dan remaja. Bandung: PT Remaja Rosdakarya.

Yusuf, S. \& Nurihsan, J. (2014). Landasan bimbingan \& konseling. Bandung: PT Remaja Rosdakarya. 